\title{
Toxin-antitoxin Systems: Classification, Biological Function and Application in Biotechnology
}

\author{
Sobhan Ghafourian*1,2, Mohammad Raftari ${ }^{3}$, Nourkhoda \\ Sadeghifard ${ }^{2}$, Zamberi Sekawi*1 \\ ${ }^{1}$ Department of Medical Microbiology and Parasitology, \\ Faculty of Medicine and Health Science, Universiti Putra \\ Malaysia, Malaysia \\ ${ }^{2}$ Clinical Microbiology Research Center, Ilam University of \\ Medical Sciences, Ilam, Iran \\ ${ }^{3}$ Faculty of Food Science and Technology, Universiti Putra \\ Malaysia, Malaysia
}

\begin{abstract}
The toxin-antitoxin (TA) systems are systems in which an unstable antitoxin inhibits a stable toxin. This review aims to introduce the TA system and its biological application in bacteria. For this purpose, first we describe a new classification for the TA systems based on how the antitoxin can neutralize the toxin, we then describe the functions of TA systems and finally review the application of these systems in biotechnology.
\end{abstract}

\section{Introduction}

The toxin-antitoxin (TA) systems are systems that an unstable antitoxin inhibits a stable toxin. Descriptions of TA systems emerged in 1982. Plasmids or chromosomes of bacteria and archaea can encode TA systems. When the TA system is encoded on a plasmid, the plasmid vertically transfers to the daughter cells; those daughter cells which do not inherit the plasmid will die because the unstable antitoxin will be degradated and the stable toxin will kill the cells (Anonymous 2013). This is called 'post-segregational killing' (PSK) (Aridani et al., 2006).

This property of the TA system has made it a unique system in prokaryotes (Fozo et al., 2010). The various biological roles of the TA system can be summarized as follows:

a) Formation of persister cells (Maisonneuve et al., 2011), b) stress resistance (Aizenman et al., 1996),

c) protection from bacteriophages (phages) (Fineran et al., 2009)

d) regulation of biofilm formation (Wang and Wood, 2011),

e) programmed cell death (PCD) and others.

TA systems can be classified into four groups: Type I TA systems, non-coding small RNA antitoxin inhibits the mRNA of the toxin by degradation via RNase III or by hiding the Shine-Dalgarno sequence (Fozo et al., 2010). Type II TA systems: an antitoxin protein binds to a toxin protein and causes neutralization (Leplae et al., 2011); Type III TA systems: the protein toxin is directly bound to a RNA

*Corresponding author: Email: szamberi@yahoo.com, sobhan.ghafurian@gmail.com molecule (Blower et al., 2011). Recently a type IV TA system was described: antitoxin directly inhibits the mRNA toxin (Wang et al., 2012).

This article focuses on the biological application of TA systems in bacteria. Firstly, we introduce a new classification of TA systems; we then describe the function of TA systems and finally review the application of these systems in biotechnology.

\section{Classification of TA systems}

How can the antitoxin neutralize the toxin? The answer to this question is the basis of the classification of TA systems. Thus, they have been classified into four types.

\section{Type I TA systems}

In this type of TA system, the antitoxin is a small molecule called sRNA. The sRNA is able to bind to the mRNA of the toxin and this results in inhibition of the translation of antitoxin mRNA by degradation via RNase III or by hiding of the Shine-Dalgarno sequence (defined as a ribosomal binding site in the mRNA, it is located eight base pairs upstream of the start codon) (Van Melderen et al., 2009). Typically, the type I toxin is small (>60 amino acids) with an abundance of hydrophobic protein (Hayes, 2003). The encoding of toxin and antitoxin is almost always on opposite strands of the DNA. Because of the fact that the toxin in type I TA systems is too toxic for the host, there is a little information about the intracellular target of type I TA systems (Wagner et al., 2012). The example of type I is the well-characterized hok/sok TA system (the hok is toxin and sok antitoxin). Interestingly, in this type I TA system, a third protein exists which, in the case of hok/sok, is called mok (Fineran et al., 2009). The role of this third protein (mok) is the assistance of translation of the toxin, because the open reading frame has overlaps to the toxin thus it is possible that the antitoxin directly binds to the third component and inhibits the toxin translation (Fozo et al., 2010). The other examples of type I TA systems are Idr/Rdl, tisB/lstR1, ibs/Sib, shoB/OhsC and symE/SymR which are found in E. coli (Kawano, 2012; Fozo, 2012). The first identified type I TA system in grampositive bacteria was fst/RNAll, which acts as the hok/sok TA system. The fst/RNAII TA system first was reported in Enterococcus faecalis in 1989.

The fst/RNAII TAsystem was also was found on plasmids of Staphylococcus saprophyticus, Lactobacillus casei and Listeria monocytogenes. txpA/RatA is choromosomal type I TA system which was found in Bacillus subtilis in 2005 (Durand, 2012).

\section{Type II TA systems}

In type II the unstable antitoxin inhibits the stable toxin. The instability of the antitoxin can be explained by a less ordered structure, resulting in more sensitivity to proteolytic degradation (Figure 2) (Yamaguchi et al., 2011). The length of toxin in type II TA systems is around 100 amino acids (Fozo et al. 2008), with the intracellular targets for the toxin 


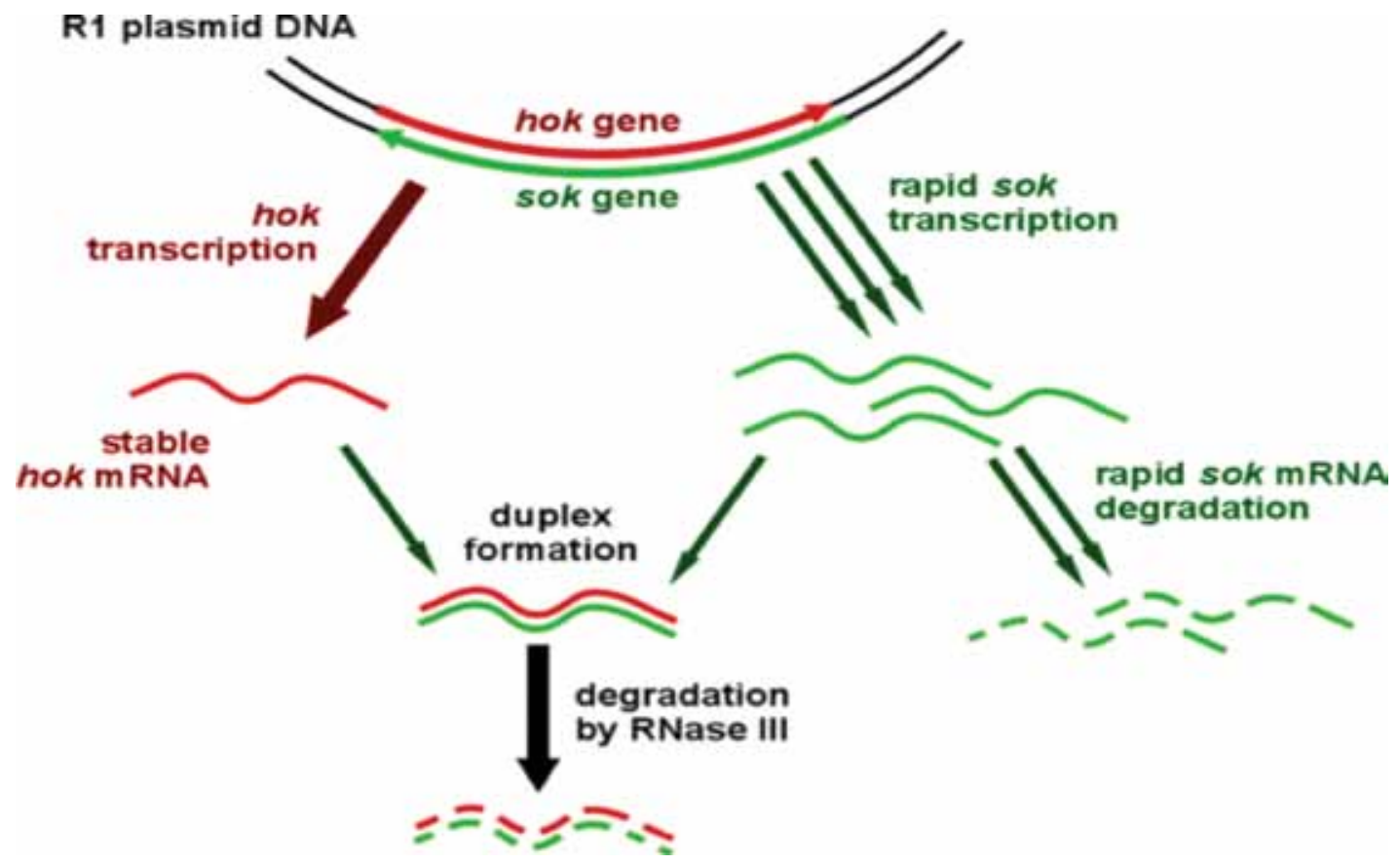

Figure 1. Type I TA system (hok/ sok). Degradation of toxin produced by RNaselll (from Anonymous 2013).

being different among different families of type II TA systems, some examples are: CcdB protein, effected to DNA gyrase by poisoning DNA topoisomerase II (Bernard and Couturier, 1992), whereas the MazF protein was found to be an endoribonuclease which cleaves cellular mRNAs at specific sequence motifs (ACA) (Hang et al., 2003). Depending on the toxin, the intracellular targets are different and include DNA gyrase, ribosome, elongation factor thermal unstable or uridine diphosphate- $\mathrm{N}$-acetylglucosamine (Yamaguchi et al., 2011). However, the most common toxic activity is as an endonuclease, and this is known as an interferase (Christensen-Dalsgaard et al., 2008).

Like type I TA systems, it was found that a third protein

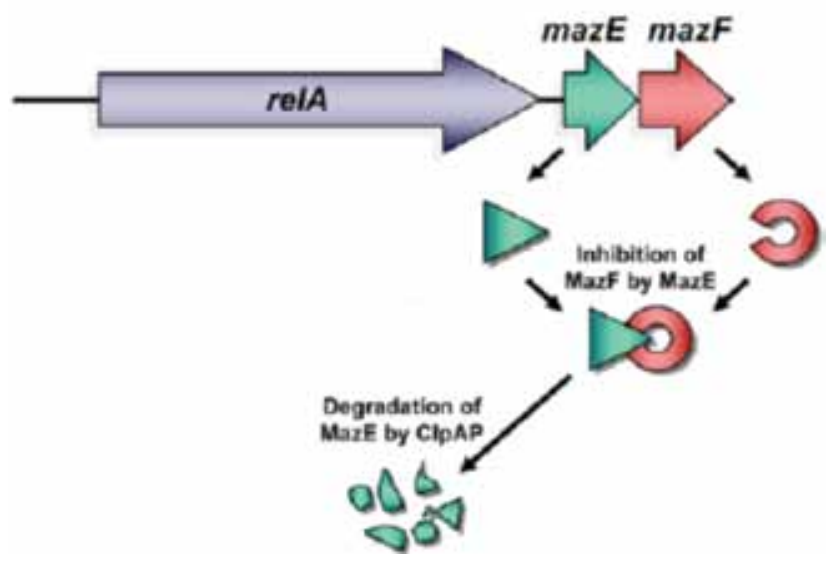

Figure 2. Neutralization of MazF by MazE and degradation of MazE by ClpAP (protease) (from Vesper et al. 2011). is involved in type II TA systems. For example in MazEF TA system, MazG was found as a regulatory protein which can bind to MazF and inhibit the toxin (Gross et al., 2006).

\section{Type III TA systems}

The ability of bacteria to be resistance to phage infection led to the identification of type III TA systems (Fineran et al., 2009). In this case the RNA antitoxin directly neutralizes the protein toxin (Blower et al., 2011). Within each Type III locus, a toxin gene is preceded by a short palindromic repeat, which is itself preceded by a tandem array of nucleotide repeats. The short palindromic repeat acts as a transcriptional terminator, regulating the relative levels of antitoxic RNA and toxin transcript (Figure 3) (Fineran et al., 2009). The first identified Type III TA system was ToxIN, which is encoded on plasmid pECA1039 of the Gramnegative phytopathogen, Pectobacterium atrosepticum. The toxin is ToxN and the antitoxin is Toxl (Fineran et al., 2009). The crystal structure of the ToxIN complex revealed a heterohexameric triangular assembly of three ToxN proteins interspersed by three Toxl RNA pseudoknots. Endoribonuclease was found to be a target for ToxN (Blower et al., 2011). This system was found on the plasmids and chromosomes of both Gram-negative and Gram-positive species, within human and animal pathogens, oceanic and soil bacteria and extremophiles (Fineran et al., 2009).

\section{Type IV TA systems}

Recently, a new type of TA system was reported by Wang et al., (Wang (A) et al., 2012) in which the antitoxin directly cleaved the mRNA toxin. They revealed GhoT (toxin) which is a membrane lytic peptide involved in ghost cell formation, that means this protein causes a lysation in cell without damage to the cell membrane, making it tolerant to antibiotics. In this new TA system the GhoS monomer 


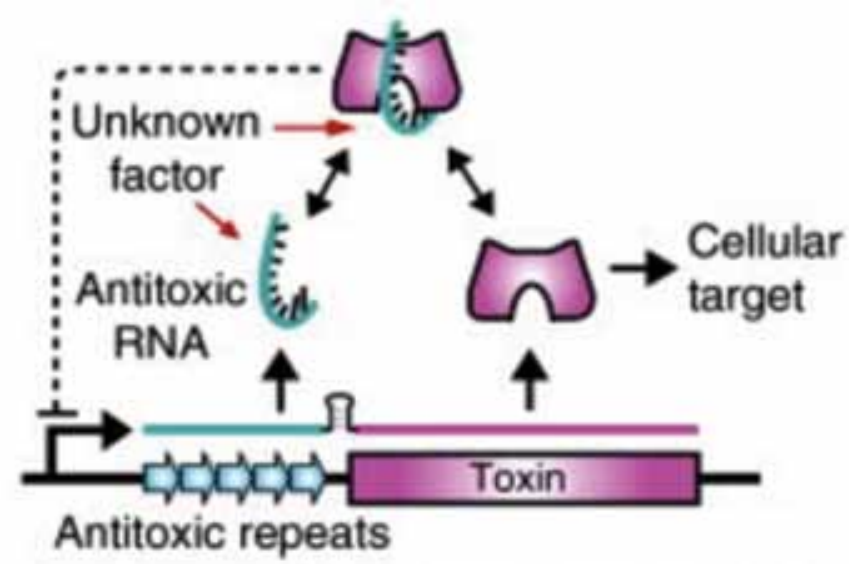

Figure 3. TypellI TA system (from Blower et al. 2011b).

cleaves the GhoT mRNA in a specific site (rich in $U$ and A). Thus, GhoS/ GhoT is a new type of TA system in which GhoS inhibits the GhoT toxin by cleaving the mRNA (Figure 4) (Wang (A) et al., 2012). This new TA system was found in Escherichia, Shigella, Salmonella, Citrobacter, and Proteus spp (Wang (B) et al., 2012).

\section{Functional analysis of TA systems}

\section{Genomic Junk}

One of the functions for chromosomal TA systems can be explained in the context of junk, in which they code functional non-coding RNA, which they get from a plasmid and will be lost in due course. Although rare, this occurs in their addictive qualities (Ochman and Davalos, 2006).

\section{TA system is Selfish}

Studies in some bacteria such as $E$. coli emphasis that the TA systems did not exist before indifferent strains, suggesting a non-physiological role for TA systems. On the other hand, the independence between toxin and antitoxin is strong, and they can easily move from one strain to the other by horizontal transfer and they maintain themselves in bacterial populations, thus their stabilization properties indicate their selfish behavior (Melderen et al., 2009).

\section{Gene regulation}

The study of Wai Ting Chan et al., (Chan et al., 2011) of TA system Type II (yefM-yoeB) showed they have a regulator role. They showed that the purified YefMSpn antitoxin and the YefM-YoeBSpn TA system complex binds to a palindrome sequence encompassing the -35 region of the main promoter (PyefM2) of the operon. This led to negative auto regulation with respect to PyefM2, since YefMSpn behaved as a weak repressor with YoeBSpn as a co-repressor. They found the box elements $(A, C)$ upstream of the promoter of PyefM2. The box sequences are pneumococcal, and may it be related to some bacterial behavior such as phase variation, virulence regulation, and genetic competence. Intriguingly, the coupling of the boxAC element to PyefM1 and yefMSpn in cis (but not in trans) led to transcriptional activation, indicating that the regulation of the yefM-yoeBSpn locus differs somewhat from that of other TA loci and may involve an as yet unidentified element.

\section{Surveillance in bacteria}

The activation of TA systems most often occurs in stress conditions. It should also be mentioned that most enzymes (RNase toxins) are more bactiostatic than bactericidal, thus this activation helps the bacteria to survive during starvation or stress condition (Pedersen et al., 2002).

\section{Persisters of the cells by TA systems}

First we define the term of "persister", as those cells which are able to be survive in a high concentration of antibiotic. This phenomenon is more observed in stationary phase of bacterial growth (Harrison, 2009). The TA system can be important for making persister cells, some studies showed that those cells in which the TA system was deleted are not persister. In the MqsR/MqsA TA system, this phenomenon is important also in biofilm formation (Lewis, 2008).

\section{Programmed cell death}

As mentioned, the antitoxin causes the neutralization of toxin, when the antitoxin is degraded the toxin kills the bacteria, a phenomenon that could be called PCD (Hayes, 2003).

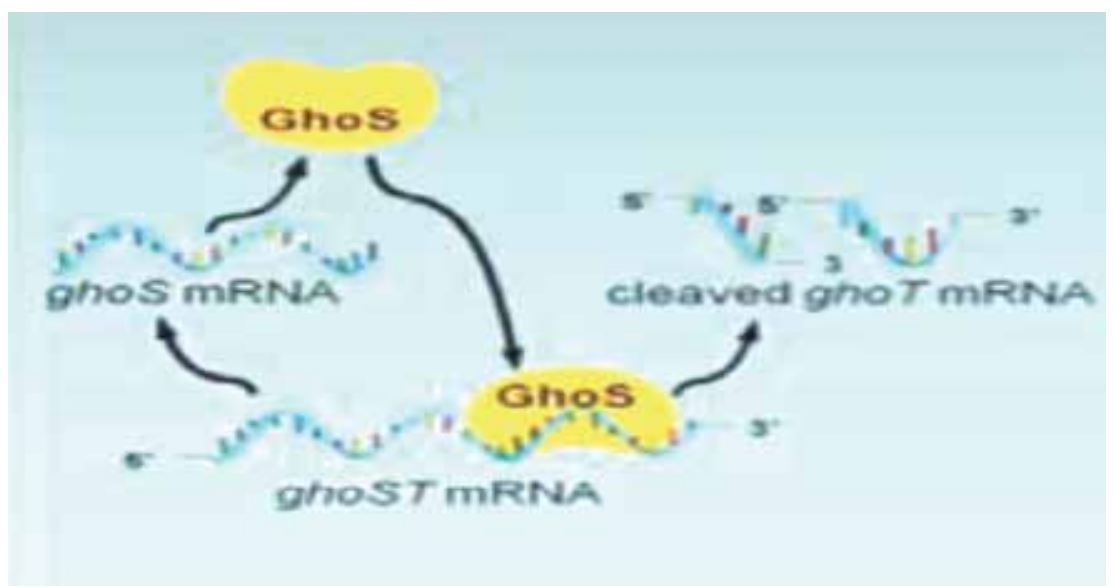

Figure 4. Type $\mathrm{V}$ TA systems whereas antitoxin (GhoS) cleaved the mRNA toxin (GhoT) (from Wang et al. 2012b). 

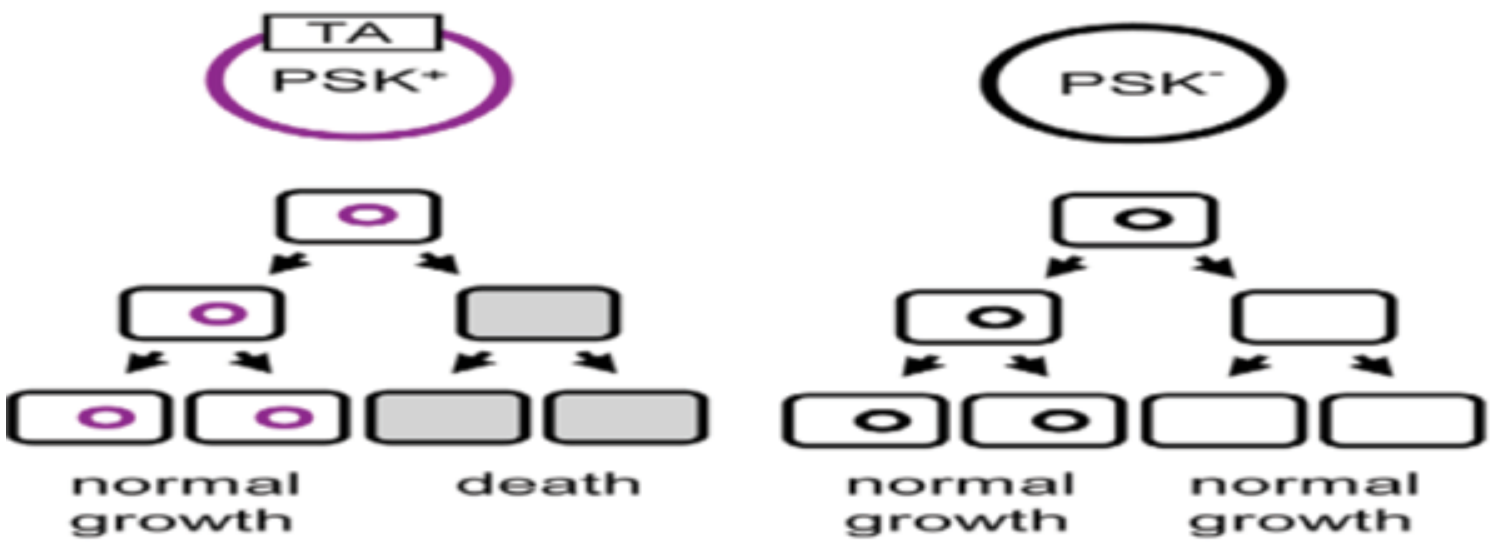

Figure 5. Vertical gene transfer among TA system. TA systems increase plasmid prevalence in growing bacterial populations by post-segregational killing (PSK) (from Melderen and Saavedra, 2009).

\section{Antiphage activity}

Another role that can be defined for TA systems is antiphage activity. By activation of this system the production of phage is reduced (Pecota and Wood, 1996).

\section{Plasmid maintenance}

Plasmid maintenance can be explained by vertical gene transfer. Due to the unstable antitoxin in cells that do not inherit the plasmid, these cells cannot reutilize the toxin, and this results in cell death. However, cells which inherit the TA system plasmid will remain alive. This can explain the role of the TA system in plasmid maintenance (Aridani et al., 2006).

\section{Biofilm formation}

Several studies suggested the role of TA systems in biofilm formation. For example they showed that MqsR is induced in E. coli biofilms, and this increased expression enhances cell motility, whereas deletion of the MqsR gene inhibits biofilm formation (Gonzalez Barrios, 2006). However it is unclear whether MqsR has a direct role for biofilm formation. They showed that in some mutants in which five TA systems were deleted ( $\Delta$ mazEmazF, $\Delta$ relBrelE, $\Delta$ yefMyoeB $\Delta$ dinJyafQ, $\triangle$ chpBlchpBK), biofilm formation was reduced during the first 8 hours but then recovered to normal levels (Kim, 2009). However, the implications of this finding for the role of TA systems in biofilm formation are not clear at present.

The study by Pandey and Gerdes showed that the TA system is correlated to bacterial life style; they showed that the system is more common in free-living bacterial species than the in obligative intracellular bacteria. This is because the free-living bacteria are more exposed to stress conditions and can cope under various different stress conditions (Pandey and Gerdes, 2005). In addition, the horizontal transfer of the system provides a mechanism against invading DNA such as phage (Pecota and Wood, 1996).

\section{Application of TA systems}

The applications of TA systems can be summarized as a follows.

\section{TA system as an antimicrobial target}

The TA system has a potential as an antimicrobial target in bacteria. As a mentioned above the PCD is one of the mechanisms for discussion concerning the use of the TA system as an antimicrobial target. For example there is the role of several antibiotics which indirectly act against TA systems. These antibiotics can be classified in two groups:

1) The antibiotics which inhibit translation

2) The antibiotics that inhibit folic acid metabolism which results in thymine starvation.

The current information and crystal structure of MazEF TA systems (Loris, 2003) may lead to the design of a new antibiotic which directly acts against TA systems.

The challenges are determining the crystal structure of each TA system. This can help us to understand the interaction of toxin and antitoxin and lead to the design of new chemical drugs as a crystal structure. Also, identifying the types of TA systems, whether functional or not, and the location in bacteria (chromosome or plasmid) will provide a fundamental understanding of possible applications as antibiotic targets.

\section{TA systems as a tool for studying in anti-paralysis vaccine}

With TA systems assays, it will be possible to characterize the amount of antitoxin, which is needed for neutralizing the toxin. This technique can be applied to the paralysis toxin of the paralysis tick of Australia, Ixodes holocyclus. In this case, a salivary toxin of the Australian paralysis tick Ixodes holocyclus was identified and immunity to tick paralysis was studied (Stone et al., 1982). The practical application of the proposed antitoxin assay to the standardization of commercial tick-paralysis antiserum depends on regular availability of toxin and the ability to accurately standardize these supplies of toxin.

\section{TA system as a reporter gene}

A TA system can act as a reporter gene, in which only the cloned cell can be chosen in cloning. Bernard et al. in 1994 did the first study. They used the CcdB TA system as a reporter (Tieber et al. 2008). The challenge however 
concerns the different conditions (stress and others) that affect the different behavior of this system as a reporter.

\section{TA system as a plasmid maintenance for protein production}

Plasmid instability is one of the problematic issues in the use of bacteria for protein production. The loss of plasmid during cell division of bacteria can result in a population of bacteria lacking cloned gene. For this reason, the use of a TA system for maintenance of plasmid and killing the plasmid-free bacterial cells is possible. For selection of bacteria in cloning the use of antibiotic is common; but in this case, the advantage is stabilization of vector without antibiotics (Tieber et al., 2008). The challenge will be the selection of suitable TA systems which can be expressed in gram-positive and gram-negative host.

\section{Declaration of interest}

The current review supported by the Department of Medical Microbiolgy and Parasitology, Faculty of Medicine and Health Sciences, Universiti Putra, Malaysia.

\section{References}

Anonymous (2013) Wikipedia article. Toxin antitoxin system. http://en.wikipedia.org/wiki/Toxin-antitoxin_system.

Aridani, O. R., Nikravesh, A., Pandey, D.P., Gerdes, K., and Good, L. (2006). Competitive inhibition of natural antisense Sok-RNA interactions activates Hok-mediated cell killing in Escherichia coli. Nucleic Acids Res. 34, 5915-22.

Aizenman, E., Engelberg-Kulka, H., and Glaser, G. (1996). An Escherichia coli chromosomal 'addiction module' regulated by guanosine 30,50-bispyrophosphate: a model for programmed bacterial cell death. Proc. Natl Acad. Sci, 93, 6059-6063.

Bernard, P., and Couturier, M. (1992). Cell killing by the $F$ plasmid $\mathrm{CcdB}$ protein involves poisoning of DNAtopoisomerase II complexes. J. Mol. Biol. 226, 735-45.

Bernard, P., Gabant, P., Bahassi, E.M., and Couturier, M. (1994). Positive-selection vectors using the $\mathrm{F}$ plasmid ccdB killer gene. Gene, 148, 71-74.

Blower, T.R., Pei, X.Y., Short, F.L., Fineran, P.C., Humphreys, D.P., Luisi, B.F., and Salmond, G.P.C. (2011a). A processed noncoding RNA regulates an altruistic bacterial antiviral system. Nat Struct Mol Biol. 18, 185-190.

Blower, T.R., Salmond, G.P.C., and Luisi, B.F. (2011b). Balancing at survival's edge: the structure and adaptive benefits of prokaryotic toxin-antitoxin partners. Curr. Opinion Structural Biol. 21, 109-118.

Chan, W.T., Nieto, C, Harikrishna, J.H., Khoo, S.K., Othman R.Y., Espinosa, M., and Yeo, C.C. (2011). Genetic Regulation of the yefM-yoeB Toxin-Antitoxin Locus of Streptococcus pneumoniae. J. Bacteriol. 193, 4612-4625.

Christensen-Dalsgaard, M., Overgaard, M., Winther, K.S., and Gerdes K. (2008). RNA decay by messenger RNA interferases. Meth Enzymol, 447, 521-35.

Durand, S., Jahn, N., Condon, C., and Brantl, S. (2012). Type I toxin-antitoxin systems in Bacillus subtilis. RNA Biol, 9.

Fineran, P.C., Blower, T.R., Foulds, I.J., Humphreys, D.P., Lilley, K.S., and Salmond, G.P. (2009). The phage abortive infection system, ToxIN, functions as a protein-RNA toxin- antitoxin pair. Proc Natl Acad Sci, 106, 894-899.

Fozo, E.M., Hemm, M.R., and Storz, G. (2008). Small toxic proteins and the antisense RNAs that repress them. Microbiol Mol Bio Rev. 72, 579-89.

Fozo, E.M., Makarova, K.S., Shabalina, S.A., Yutin, N., Koonin, E.V., and Storz, G. (2010). Abundance of type I toxin-antitoxin systems in bacteria: searches for new candidates and discovery of nove families. Nucleic Acids Res, 38, 3743-59.

Fozo, E.M. (2012). New type I toxin-antitoxin families from "wild" and laboratory strains of E. coli: Ibs-Sib, ShoBOhsC and Zor-Orz. RNA Biol , 9.

Gross, M., Marianovsky, I., and Glaser, G. (2006). MazG - a regulator of programmed cell death in Escherichia coli. Mol Microbiol, 59, 590-601.

Gonzalez -Barrios, A.F. (2006). Autoinducer 2 controls biofilm formation in Escherichia coli through a novel motility quorum-sensing regulator (MqsR, B3022). J Bacteriol, 188, 305-316.

Hayes, F. (2003). Toxins-antitoxins: plasmid maintenance, programmed cell death, and cell cycle arrest. Science, 301, 1496-1499.

Hang, Y., Zhang, J., Hoeflich, K.P., Ikura, M., Qing, G., and Inouye, M. (2003). MazF cleaves cellular mRNAs specifically at ACA to block protein synthesis in Escherichia coli. Mol. Cell 12, 913-23.

Harrison, J.J. (2009). The chromosomal toxin gene yafQ is a determinant of multidrug tolerance for Escherichia coli growing in a biofilm. Antimicrob. Agents Chemother, 53, 2253-2258.

Kawano, M. (2012). Divergently overlapping cis-encoded antisense RNA regulating toxin-antitoxin systems from $E$. coli: hok/sok, Idr/rdl, symE/symR. RNA Biol, 9.

Kim, Y., Wang, X., Ma, Q., Zhang, X.S., and Wood, T.K. (2009). Toxin-antitoxin systems in Escherichia coli influence biofilm formation through YjgK (TabA) and fimbriae. J Bacteriol, 191, 1258-1267.

Leplae, R., Geeraerts, D., Hallez, R., Guglielmini, J., Dreze, P., and Van Melderen, L. (2011). Diversity of bacterial type II toxinantitoxin systems: a comprehensive search and functional analysis of novel families. Nucleic Acids Res, 39, 5513-5525.

Lewis, K. (2008). Multidrug tolerance of biofilms and persister cells, p. 107-131. In T. Romeo (ed.), Bacterial biofilms. Springer-Verlag, Berlin, Germany.

Loris, R. (2003). Crystal structure of the intrinsically flexible addiction antidote MazE. J. Biol. Chem. 278, 2825228257.

Maisonneuve, E., Shakespeare, L.J., Jorgensen, M.G., and Gerdes, K. (2011). Bacterial persistence by RNA endonucleases. Proc Natl Acad Sci, 108, 13206-13211.

Melderen, L.V., and Saavedra De Bast, M. (2009). Bacterial toxin-antitoxin systems: more than selfish entities? PLoS Genetics. 5, 1-6.

Ochman, H., and Davalos, L.M. (2006). The nature and dynamics of bacterial genomes. Science, 311, 17301733.

Pandey, D.P., and Gerdes, K. (2005). Toxin-antitoxin loci are highly abundant in free-living but lost from hostassociated prokaryotes. Nucleic Acids Res, 33, 966-976.

Pecota, D.C, and Wood, T.K. (1996). Exclusion of T4 phage by the hok/sokkiller locus from plasmid R1. J Bacteriol, 178, 2044-2050. 
Pedersen, K., Christensen, S.K, and Gerdes, K. (2002). Rapid induction and reversal of a bacteriostatic condition by controlled expression of toxins and antitoxins. Mol Microbiol. 45, 501-510.

Stone, B.F., Cowie, M.R., Kerr, J.D., and Binnington, K.C. (1982). Improved toxin/antitoxin assays for studies on the Australian paralysis tick Ixodes holocyclus. Aust J Exp Biol Med Sci. 60. 309-18.

Tieber, D., Gabant, P., and Szpirer, C. (2008). The art of selective killing: plasmid toxin/antitoxin systems and their technological applications. BioTechniques. 45, 344-6.

Van Melderen, L., and Saavedra De Bast, M. (2009). Bacterial Toxin-Antitoxin Systems: More Than Selfish Entities? PLoS Genet. 5, e1000437.

Vesper, O., Amitai, S., Belitsky, M., Byrgazov, K., Kaberdina, A.C., Engelberg-Kulka H. and Moll, I. (2011). Selective translation of leaderless mRNAs by specialized ribosomes generated by MazF in Escherichia coli. Cell. $147,147-157$.
Wang, X., and Wood, T.K. (2011). Toxin-antitoxin systems influence biofilm and persister cell formation and the general stress response. Appl Environ Microbiol. 77, 5577-5583.

Wang, X., Lord, D.M., Cheng, H.Y., Osbourne, D.O., Hong, S.H., and Sanchez-Torres, V. (2012a). A new type $\mathrm{V}$ toxin-antitoxin system where mRNA for toxin GhoT is cleaved by antitoxin GhoS. Nat. Chem. Biol. 8, 855-861.

Wang, X., Lord, D.M., Hong, S.H., Peti, W., Benedik, M.J., and Wood, T.K. (2012b). Type II Toxin/Antitoxin MqsR/ MqsA Controls Type V Toxin/Antitoxin GhoT/GhoS. Applied Microbiol. In press.

Wagner, E. G. H., and Unoson, C. (2012). The toxin-antitoxin system tisB-istR1: Expression, regulation, and biological role in persister phenotypes. RNA Biol. 9.

Yamaguchi, Y., Park, J., and Inouye, M. (2011). Toxinantitoxin systems in bacteria and archaea. Ann. Rev Genet. 45, 61-79. 


\section{Further Reading}

Caister Academic Press is a leading academic publisher of advanced texts in microbiology, molecular biology and medical research. Full details of all our publications at caister.com

- MALDI-TOF Mass Spectrometry in Microbiology Edited by: M Kostrzewa, S Schubert (2016) www.caister.com/malditof

- Aspergillus and Penicillium in the Post-genomic Era Edited by: RP Vries, IB Gelber, MR Andersen (2016) www.caister.com/aspergillus2

- The Bacteriocins: Current Knowledge and Future Prospects Edited by: RL Dorit, SM Roy, MA Riley (2016)

www.caister.com/bacteriocins

- Omics in Plant Disease Resistance Edited by: V Bhadauria (2016) www.caister.com/opd

- Acidophiles: Life in Extremely Acidic Environments Edited by: R Quatrini, DB Johnson (2016) www.caister.com/acidophiles

- Climate Change and Microbial Ecology: Current Research and Future Trend

Edited by: J Marxsen (2016)

www.caister.com/climate

- Biofilms in Bioremediation: Current Research and Emerging Technologies

Edited by: G Lear (2016)

www.caister.com/biorem

- Microalgae: Current Research and Applications Edited by: MN Tsaloglou (2016) www.caister.com/microalgae

- Gas Plasma Sterilization in Microbiology: Theory, Applications, Pitfalls and New Perspectives Edited by: H Shintani, A Sakudo (2016) www.caister.com/gasplasma

- Virus Evolution: Current Research and Future Directions Edited by: SC Weaver, M Denison, M Roossinck, et al. (2016) www.caister.com/virusevol

- Arboviruses: Molecular Biology, Evolution and Control Edited by: N Vasilakis, DJ Gubler (2016) www.caister.com/arbo

- Shigella: Molecular and Cellular Biology Edited by: WD Picking, WL Picking (2016) www.caister.com/shigella

-Aquatic Biofilms: Ecology, Water Quality and Wastewater Treatment

Edited by: AM Romaní, H Guasch, MD Balaguer (2016)

www.caister.com/aquaticbiofilms

- Alphaviruses: Current Biology

Edited by: S Mahalingam, L Herrero, B Herring (2016)

www.caister.com/alpha

- Thermophilic Microorganisms

Edited by: F Li (2015)

www.caister.com/thermophile
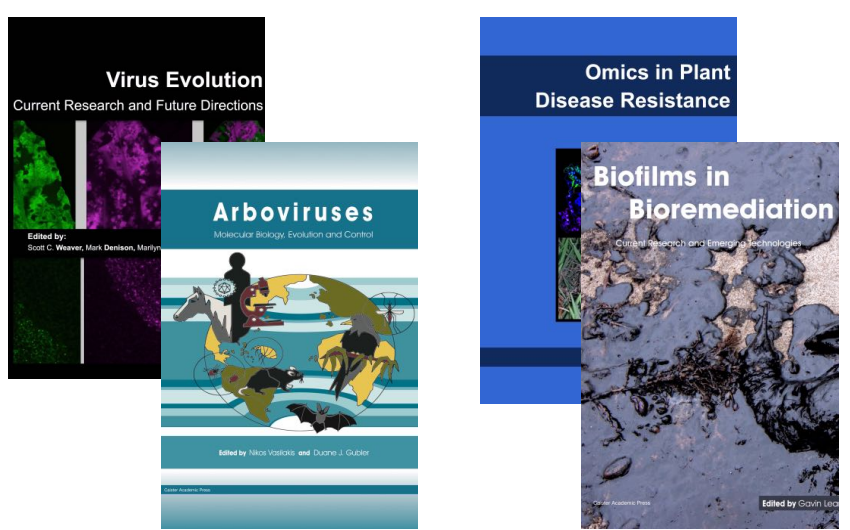
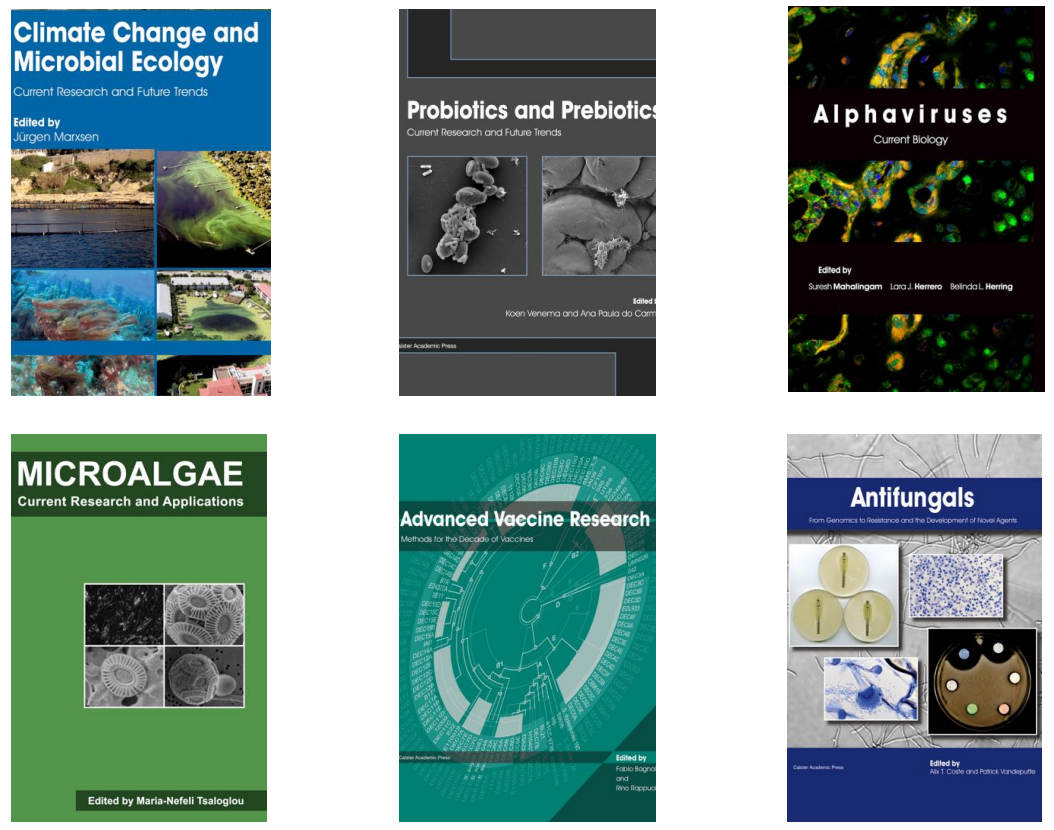

- Flow Cytometry in Microbiology: Technology and Applications Edited by: MG Wilkinson (2015) www.caister.com/flow

- Probiotics and Prebiotics: Current Research and Future Trends Edited by: K Venema, AP Carmo (2015) www.caister.com/probiotics

- Epigenetics: Current Research and Emerging Trends Edited by: BP Chadwick (2015) www.caister.com/epigenetics2015

- Corynebacterium glutamicum: From Systems Biology to Biotechnological Applications

Edited by: A Burkovski (2015)

www.caister.com/cory2

- Advanced Vaccine Research Methods for the Decade of Vaccines

Edited by: F Bagnoli, R Rappuoli (2015)

www.caister.com/vaccines

- Antifungals: From Genomics to Resistance and the Development of Novel Agents

Edited by: AT Coste, P Vandeputte (2015)

www.caister.com/antifungals

- Bacteria-Plant Interactions: Advanced Research and Future Trends Edited by: J Murillo, BA Vinatzer, RW Jackson, et al. (2015) www.caister.com/bacteria-plant

\section{- Aeromonas}

Edited by: J Graf (2015)

www.caister.com/aeromonas

- Antibiotics: Current Innovations and Future Trends

Edited by: S Sánchez, AL Demain (2015)

www.caister.com/antibiotics

- Leishmania: Current Biology and Contro Edited by: S Adak, R Datta (2015) www.caister.com/leish2

- Acanthamoeba: Biology and Pathogenesis (2nd edition) Author: NA Khan (2015)

www.caister.com/acanthamoeba2

- Microarrays: Current Technology, Innovations and Applications Edited by: Z He (2014)

www.caister.com/microarrays2

- Metagenomics of the Microbial Nitrogen Cycle: Theory, Methods and Applications

Edited by: D Marco (2014)

www.caister.com/n2 